\title{
The Implementation Of Recollection Smart Teaching Learning Method Can Increase Learning Mathematics Result Of The Eleventh Grade Students Of IPS1 At SMA Negeri 4 Parepare
}

\author{
Arifuddin \\ Mathematic Education \\ University of Muhammadiyah ParePare \\ Indonesia \\ arif_umpar@yahoo.co.id
}

\begin{abstract}
This research was a classroom action research including planning, implementation, observation, and reflection phase which were implemented in SMA Negeri 4 Parepare which aimed to improve mathematics learning result through the implementation of learning method of smart teaching recollection utilizing students' unconsciousness in learning process. Subjects in this study were students class XI IPS1 SMA Negeri 4 Parepare 2016/2017 academic year which amounted to 26 students. The research was conducted in 2 cycles, each of cycle was conducted in 4 meetings and carried out the final test of it.The data were collected by using observation and learning result test. The data collected were analyzed by using descriptive statistic. The result of the research showed that the result of mathematics learning of students class XI IPS1 of SMA Negeri 4 Parepare increased from cycle I to cycle II through the implementation of learning method of smart teaching recollection. This could be seen from (a) the learning results in cycle I, the number of students who completed were only 9 students with an average score of 64.31 and in cycle II increased to 23 students with an average score of 78.27. (b) the increasing percentage of students' mathematics learning achievement was $34.6 \%$ in the first cycle increased to $88.5 \%$ in cycle II. (c) the average increase in the learning activities of the students from cycle I to cycle II. From the results of this research could be concluded that there was an improvement of students' mathematics learning results of class XI IPS1 at SMA Negeri 4 Parepare by implementing the teaching method of recollection smart teaching.

Keywords : Mathematics Learning Results; Smart Teaching Recollection Learning Method
\end{abstract}

\section{INTRODUCTION}

Mathematics learning is a means of thinking clearly, creatively, systematically and logically. Mathematics also plays a role in solving everyday problems, recognizing relationship patterns and generalizing experiences and developing creativity. This causes mathematics to be studied as a provision for students from elementary school to college.

Students often assume that mathematics is a science that is difficult to learn and boring, especially seeing the formula memorization that looks complicated and difficult calculations, coupled with less enjoyable learning. Actually, the method of learning is 
undirected and focused on the improvement of intellectual ability only where the teacher only provides debriefing ability of knowledge and explanation. This will certainly have an impact on the lack of motivation to learn so that the students' mathematics learning results is in less satisfactory.

Based on the results of preliminary observations conducted in class XI IPS1 SMA Negeri 4 Parepare, the researcher was obtained information that most of the mathematics learning results at the odd semester was 70 , while the Minimum Completeness Criteria (MCC) that has been established by the school that was 75 . One of the problems of this learning result due to lack of students' motivation to learn was caused by the weak teacher's role in processing the students' emotion and creating a pleasant classroom atmosphere.

The researcher chose the method of learning recollection of smart teaching as an alternative solution in overcoming the problems of mathematics learning in school. Webe (2010: 37) suggests that teachers should bring up five hidden potentials in themselves through the recollection before it becomes smart, namely:

1. Can reflect the existence of himself as a teacher

2. Can communicate effectively and efficiently

3. Having a leadership soul in leading the students

4. Implementing an excellent service and full integrity

5. Full of motivation in his life

This learning method would provide opportunities for students to empower all the potential they have, students were cheerful, joyful and more able to receive the materials taught. Actually, the teaching method of smart teaching recollection was a very simple method, many of us were using this method accidentally. Understanding this method well deliberately would show something extraordinarily conscious that was coincidentally considered in the previous time (not accidentally).

Based on the above description, the authors conducted a study in SMA Negeri 4 Parepare with the title "The Implementation of Recollection Smart Teaching Method to Improve Student' Mathematics Learning Results in Class XI IPS1 of SMA Negeri 4 Parepare".

Based on the problems background that have been stated above, then the formulation of the problem in this study was "whether by the implementation of recollection smart teaching method improve the students learning results in class XI IPS1 of SMA Negeri 4 Parepare?".

Based on the formulation of the above problem, the purpose of this study was to know that the implementation of recollection smart teaching method can improve the students' learning results in class XI IPS1 of SMA Negeri 4 Parepare.

\section{RESEARCH METHOD}

The research's type was classroom action research which the implementation included planning, action, observation, and reflection.

Subjects in this research were students of class XI IPS ${ }_{1}$ even semester at SMA Negeri 4 Parepare academic year 2016/2017 which amounted to 26 students, consisting of 14 men and 12 women. 


\section{A. Operational Definition of Variables}

Operational definitions of variables used in this research, namely:

1) The learning method of recollection smart teaching was a learning method in which the teacher communication was created with the subconscious of students so that the students' minds were more open in receiving the given materials.

2) Learning results were scores obtained by students from the tests given at each end of the cycle of mathematics learning with of recollection smart teaching learning methods.

B. Research procedure

The implementation of this action research was conducted in two cycles, where cycle I was held for four meetings and cycle II was also held for four meetings. In accordance with the nature of classroom action research, cycle II was an improvement in cycle I, then each cycle consists of: (a) planning stage, (b) action stage, (c) observation stage, and (d) reflection stage. In detail the procedures of this action research were described as follows:

1) Cycle I

a) Planning Stage

Some things must be prepared and done at this stage by researchers before acting as a teacher in the classroom for the effectiveness of the learning process, because the learning would work well if it was done a mature planning therein. As for the things that were meant were as follows:

(1) Reviewing the current curriculum in the even semester of class XI IPS1 of the academic year 2016/2017.

(2) Analyzing the subject matter to be taught.

(3) Creating a learning implementation plan at each meeting.

(4) Preparing the supporting materials.

b) Action Stage

This stage is the implementation or follow-up of the planning stage, as for what would be done was as follows:

(1) Creating an exciting opening

Teachers could tell stories or show things that are interesting to students.

(2) Explaining the students' problem

Explaining the problem faced by the students. The difficult formula problem or whatever the teacher knew was being faced by the students in relation to the teaching materials that have been taught at the previous meeting.

(3) Giving solution to the students' problem.

The teacher entered the material that was the solution of the problem in step two, and then provided the solution with the materials to be taught.

(4) Closing

The teacher closed lessons by giving homework and motivation.

c) Observation Stage 
Observation of action implementation was done by using observation sheet to record the activities that occured in the classroom during the learning process took place, then the observation sheet was made observation table used to observe the learning process in the form of attendance list and the activities of students in the learning process.

\section{d) Reflection Stage}

The results of the observation stage were collected and analyzed and then made a plan of improvement with the completion of action in cycle II.

\section{2) Cycle II}

The procedure or steps in cycle II was the same as cycle I, that was the teacher still use the teaching method of smart teaching recollection. All the obstacles that were obtained in the first cycle attempted to solve and improve on cycle II.

\section{Research Instruments}

Data retrieval in this research used instrument in the form of activity observation sheet of students, observation sheet of teacher activity, and test of mathematics learning result. The observation sheets were used to collect students' activity data and the teacher's ability to manage the learning, while the mathematics learning test was used to collect data on the success rate of learners on mathematics learning. The tests of mathematics learning result and activity observation sheet of learners that have been compiled beforehand were validated by validator which was considered to know it.

\section{Data Collection Technique}

Data collection techniques in this research were:

1) Observation technique

Data on the activities of students and teacher activity during the learning process of mathematics using the method of learning recollection smart teaching observed by researchers along with peers using observation techniques.

2) Test technique

Data on mathematics learning result of students was obtained by using the test technique at the end of each cycle.

\section{E. Data analysis technique}

Data obtained from the results of research through observation techniques and test techniques were analyzed by:

1) Activity data of students

Activity data of students obtained by using observation technique was analyzed by using the following formula: 


$$
\mathrm{NP}=\frac{\mathrm{R}}{\mathrm{SM}} \times 100
$$

(Purwanto, 2010: 102)

Information:

$\mathrm{NP}=$ percent score sought

$\mathrm{R}=$ raw score obtained

$\mathrm{SM}=$ maximum score

$100=$ fixed number

2) Teacher activity data

For the results of observation of the ability of teachers to manage the learning was analyzed by calculating the average score of each observed aspect in managing the learning of many meetings conducted in the study.

Table 1 Converting Average Scores of Teachers' Ability to Manage Learning

\begin{tabular}{|lc|}
\hline Average & Criteria \\
\hline $0,5-1,5$ & Very Poor \\
$1,6-2,5$ & Poor \\
$2,6-3,5$ & Fair \\
$3,6-4,5$ & Good \\
$4,6-5,0$ & Very Good \\
\hline
\end{tabular}

Bloom (Mulbar, 2013: 423)

3) Data of mathematics learning result of students

Data of mathematics learning result of students was analyzed by using descriptive statistic. Student learning results were described to calculate average scores, standard deviations, maximum and minimum scores. The criteria used to categorize learning results based on standards established by Nurkancana (Badolo, 2012: 16) were as follows:

Mastery $90 \%-100 \%$ was categorized as "very high"

Mastery of $80 \%$ - $89 \%$ was categorized as "high"

Mastery $65 \%$ - 79\% was categorized as "medium"

Mastery of $55 \%$ - $64 \%$ was categorized as "low"

Mastery of $0 \%-54 \%$ was categorized as "very low".

Analysis of mastery of mathematics learning results of students categorized as follows:

0-74 was categorized as "incomplete"

75-100 was categorized as "complete" 


\section{A. Success Indicators}

The success indicators of this research were:

1) The increasing of the average score of mathematics learning results of students from cycle I to cycle II.

2) The increasing of activity of learners in the process of learning mathematics from cycle I to cycle II.

The increasing of mathematics learning completeness from cycle I to cycle II, that was complete individual and thoroughly classical. Completed individuals if the student has reached the minimum completeness criteria of 75 and mastery of $65 \%$ of the subject matter controlled by students then called completed learning students, and $85 \%$ students completed learning was called classical thoroughly

\section{RESULT}

A. Research Results

1) Descriptive Analysis Result

a) The Results of the Students' Mathematical Learning in Cycle I

The result of the mathematics learning test from cycle 1 was analyzed by descriptive analysis using SPSS 21 program. The result score data of students' mathematics learning from cycle I test can be seen in Table 4.1 as follows:

\section{Table 4.1 Statistics Score of Students' Mathematics Results in Cycle I}

\begin{tabular}{lc} 
Statistic & Statistic scores \\
\hline Subjects & 26 \\
\hline Average score & 64,31 \\
\hline Median & 65,00 \\
\hline Standard Deviation & 15,64 \\
\hline Variance & 244,46 \\
\hline Gain Score & 45 \\
\hline Minimum Score & 35 \\
\hline Maximum Score & 80 \\
\hline Ideal score & 100
\end{tabular}

Based on Table 4.1 it can be seen that the average score of learning results of mathematics students in cycle I using the method of learning recollection smart teaching is equal to 64.31 , with the lowest score reached 35 and the highest score 80 of the ideal score 100. If the score of students' mathematics learning ability were grouped into five criteria 
of categorization of mathematics learning results, then it would be obtained the frequency distribution and percentage in Table 4.2 as follows:

Table 4.2 Distribution of Frequency and Percentage of Students' Mathematics Learning Result in Cycle

\begin{tabular}{llll} 
Mastery Level & \multicolumn{4}{l}{ Category of Percentage Frequency } \\
\hline $0 \%-54 \%$ & Very low & 7 & 26,9 \\
\hline $5 \%-64 \%$ & Low & 4 & 15,4 \\
\hline $65 \%-79 \%$ & Fair 1038,5 & \\
\hline $80 \%-89 \%$ & \multicolumn{3}{l}{ High 519,2 } \\
\hline $90 \%-100 \%$ & Very High 00,0 & \\
\hline & Total 26 & 100,0
\end{tabular}

Based on the Table 4.2 showed that the percentage of students' learning achievement score after applying the teaching method of recollection smart teaching in cycle I was not obtained by the students that included in a very high learning category, high category was 5 students (19.2\%), fair category was 10 students $(38,5 \%)$, low category was 4 students $(15,4 \%)$, and very low category was 7 students $(26,9 \%)$ of 26 students.

Based on the results of data analysis in Table 4.1 showed the average score of learning ability of students in the first cycle was 64.31. If the average score of students' mathematics learning results was categorized in the criteria of the categorization of mathematics learning results, then the average score of students was in the low category. Furthermore, if the mathematics learning results of students in the first cycle was analyzed with the percentage of students' mastery of mathematics learning, so that it can be seen in Table 4.3 below:

Table 4.3 Frequency Distribution and Percentage Completion of Students' Mathematics Learning in Cycle I

T. Completeness of Score Interval of Frequency

Category

\begin{tabular}{lclc}
$75 \%-100 \%$ & $75-100$ & Complete & 9 \\
$0 \%-74 \%$ & $0-74$ & Tidak Incomplete & 17 \\
\hline
\end{tabular}

Total 26

Based on Table 4.3, it showed that there were 9 students or $34.6 \%$ of the 26 students were in the complete category and 17 students or $65.4 \%$ were in the incomplete category. If the completeness was based on the classical completeness category, then the result of students' mathematics learning after learning with recollection smart teaching method in the first cycle has not been completed in a classical. 
b) The results of the participants' mathematics learning were II

Descriptive statistical analysis of students' mathematics learning results based on test results in cycle II can be seen in Table 4.4 below:

Table 4.4 Statistics Score of Students' Mathematics Learning Results in Cycle II

\begin{tabular}{lc}
\multicolumn{1}{c}{ Statistic } & Statistic Score \\
\hline Subject & 26 \\
\hline Average score & 78,27 \\
\hline Median & 82,50 \\
\hline Standard Deviation & 12,57 \\
\hline Variance & 157,88 \\
\hline Gain Score & 50 \\
\hline Lowest Score & 40 \\
\hline Highest Score & 90 \\
\hline Ideal Score & 100
\end{tabular}

Based on Table 4.4, it can be seen the average score of students' mathematics learning results in cycle II by implementing recollection smart teaching learning method was equal to 78.27, with the lowest score reached 40 and the highest score reached 90 of the ideal score was 100 or the score of students' mathematics learning were grouped into five criteria of categorization of mathematics learning results, then developed the distribution and percentage in Table 4.5 below:

Table 4.5 Distribution of Frequency and Percentage of Students' Mathematics Learning Results in Cycle II

\begin{tabular}{|c|c|c|c|}
\hline Mastery & Level C & ategory & Score of Percentage Frequency \\
\hline $0 \%-54 \%$ & $0-54$ & Very Low & 27,7 \\
\hline $55 \%-64 \%$ & $55-64$ & Low & 13,8 \\
\hline $65 \%-79 \%$ & $65-79$ & Fair & 415,4 \\
\hline $80 \%-89 \%$ & $80-89$ & High & 1765,4 \\
\hline $90 \%-100 \%$ & $90-100$ & Very High & 27,7 \\
\hline
\end{tabular}

Based on Table 4.5, it showed that the frequency and percentage of students' learning achievement score after being given learning action through recollection smart teaching method in cycle II was obtained by students who were categorized as very high learning results as much as 2 students $(7.7 \%)$, high category is 17 students $(65,4 \%)$, fair 
category is 4 students $(15,4 \%)$, low category was 1 student $(3,8 \%)$, and very low category was 2 students $(7,7 \%)$ of 26 students.

Based on the results of data analysis in Table 4.4, it showed that the average score of learning ability of students in cycle II was 78.27. If the average score of mathematics learning results of students was included in Table 4.5, then the average score of students was in the fair category. Furthermore, if the mathematics learning results of students in cycle II T. Interval Completeness Score of Frequency Category were

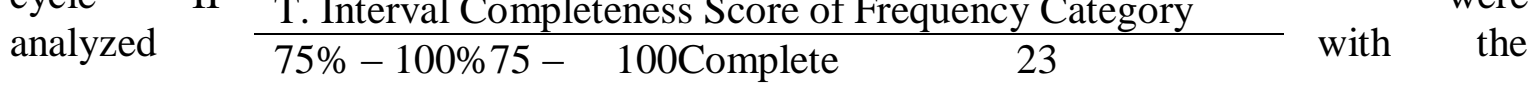
\begin{tabular}{lll}
$0 \%-74 \% 0-74$ & Incomplete & 3 \\
\hline Jumlah26 100 &
\end{tabular}

completeness percentage of students' mathematics learning, it can be seen in Table 4.6 below:

Tabel 4.6 Distribution of Frequency and Percentage of Students' Mathematics Learning Completeness in Cycle II

TABLE VI. STATISTICS SCORE OF STUDENTS' MATHEMATICS

LEARNING RESULTS IN CYCLE II

\begin{tabular}{c|c}
\hline Statistic & Statistic Score \\
\hline Subject & 26 \\
Average Score & 78,27 \\
Median & 82,50 \\
Standard Dviation & 12,57 \\
Variance & 157,88 \\
Gain Score & 50 \\
Highest Score & 40 \\
Lowest Score & 90 \\
Ideal Score & 100 \\
\hline
\end{tabular}

Based on Table 4.6, it showed that 23 students or $88.5 \%$ of students were in the complete category. If the completeness was based on the classical completeness category, then the result of students' mathematics learning by applying the teaching method of recollection smart teaching in cycle II has reached the completeness in classical.

Improvement of mathematics learning results of students from cycle I to cycle II by using recollection smart teaching was illustrated by Diagram 4.1 below: 


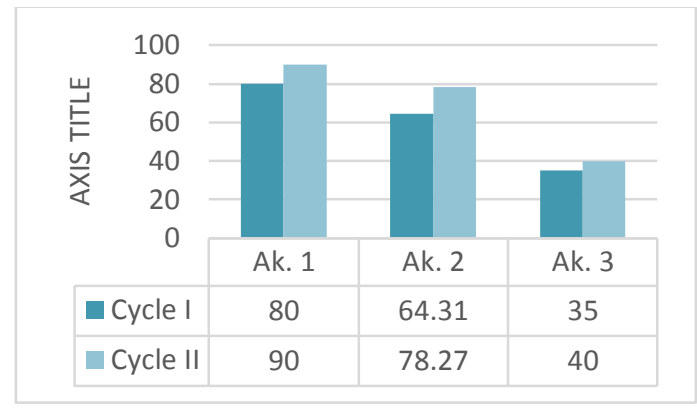

Diagram 4.1 Learning Results from Cycle I and Cycle II

Based on Diagram 4.1, it can be seen that the highest score obtained by the students have increased from cycle I to cycle II that was 80 to 90 , and the lowest score obtained by the students have increased from cycle I to cycle II that was from 35 to 40 . Furthermore, the average score increased from cycle I to cycle II that was 64,31 to 78,27 . Based on the analysis, it was concluded that the results of students' mathematics learning have increased from cycle I to cycle II with the recollection smart teaching learning method.

\section{2) Description of Observation Results}

The result of observation data on the activity of the students that have been obtained was used to observe the activity of the students in the learning process in cycle I and cycle II, while the observation data of teacher activity was used to observe the teacher's ability in managing the learning by using the teaching method of recollection smart teaching.

a) Result of Students' Activity Observation

The improvement of mathematics learning results, not apart from the activities of the students themselves. The change of students' activity is obtained from observation sheet of students' activity at each meeting recorded by the observer at each meeting. The types of activities of students observed were:

Activity 1. Students listened / listened to teacher explanations

Activity 2. Students played and did not pay attention to the teacher

Activity 3. Students asked

Activity 4. Students answered questions

Activity 5. Students completed the task individually

Activity 6. Students concluded learning materials

The comparison of the percentage of student's activity in each cycle I and cycle II can be seen in Figure 4.3 below: 


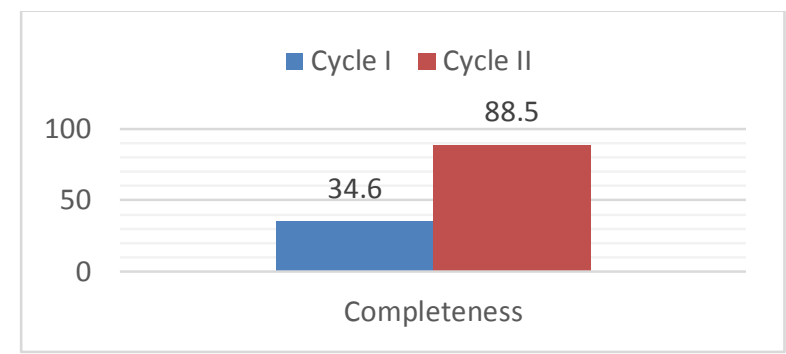

Diagram 4.3 Activities of Students from Cycle I and Cycle II

Based on Diagram 4.3, it can be seen that the percentage of students who paid attention / listened to teacher explanation during the learning was $100 \%$ in cycle I and cycle II while the percentage of students who played and did not pay attention to teachers was $0 \%$ in cycle I and cycle II. The percentage of students who asked at the learning process was $20.5 \%$ in cycle I to $29.5 \%$ in cycle II, the percentage of students who answered the question was $19.3 \%$ in the first cycle to $30.8 \%$ in cycle II, students percentage who completed the task individually was $100 \%$ in cycle I and cycle II. The percentage of learners who concluded learning materials was $6.4 \%$ in cycle I to $10.2 \%$ in cycle II.

\section{b) Observation Analysis Results of Teachers' Ability to Manage Learning through Recollection Smart Teaching Learning Method}

In this research, the observation of teacher's ability in managing the learning was done in 6 times meeting, that was in cycle I in 3 times meeting, and cycle II was also in 3 times meeting. The comparison of the average ability of teachers to manage learning in cycle I and cycle II can be seen in Diagram 4.4 below:

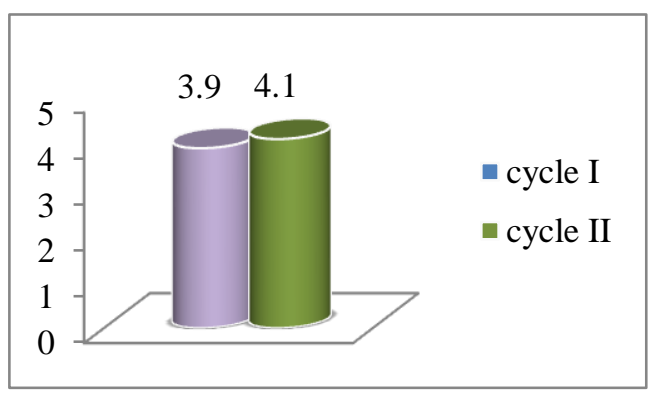

Diagram 4.4 Teachers' Ability to Manage

Based on the diagram 4.4, it can be seen that the average ability of teachers in managing learning has increased from 3.9 in the first cycle to 4.1 in cycle II, and based on the average score of the teacher's ability to manage learning through recollection smart teaching method on cycle I and cycle II were in the "good" category.

\section{B. Discussion}

\section{1) Achievement of Goals}

Achievement of research objectives was indicated by the increase of mathematics learning results of students of class XI IPS1 SMA Negeri 4 Parepare by implementing 
recollection smart teaching method based on the results of descriptive analysis that has been done.

After doing research, it was proven that the implementation of learning method of recollection smart teaching can improve students' mathematics learning results. This can be seen from the increase of students' mathematics learning results score from cycle I to cycle II, and also marked by the increasing activity of the students from cycle I to cycle II. Although there were still some things that must be addressed in this research, but from the planning of the research implementation which was only implemented in two cycles that has been obtained the fact that the results of students' mathematics learning was increased.

\section{2) Specific Findings}

Specific findings revealed were findings that were directly related to teachers and students of class XI IPS1 of SMA Negeri 4 Parepare during the process of mathematics learning took place using the method of recollection smart teaching. Specific findings obtained during the course of the research included:

a) The time allocation in the RPP was sometimes significantly different than the time spent in the lesson.

b) Students who got praise from the teacher after successfully answering the given questions look more eager in following the lesson.

c) Students revealed that the learning done by researchers was very interesting and different than other mathematics teachers.

d) Constraints experienced during the study

The constraints faced during this research were as follows:

a) In cycle I, most students were still shy and did not dare to ask the teacher, to answer questions from the teacher, and to make conclusions on the material that has been studied.

b) Most students did their homework at school.

c) Lack of students prerequisite knowledge of learning materials.

d) Students felt a little difficult in the process of understanding the subject matter with terms that were rarely heard in everyday life.

3) Research weaknesses

Weaknesses that existed during the research process was the subject in this study only focused on one class that was in class XI IPS1, so the input and responses obtained not too much.

\section{CONCLUSION:}

Based on the results of data analysis and discussion, it can be concluded that the results of mathematics learning after applying the method of recollection smart teaching on the students of class XI IPS1 at SMA Negeri 4 Parepare was increased. This was indicated by:

1) Increasing the average score of students' mathematics learning results from cycle I to cycle II that was equal to 13.96 from 64.31 in the first cycle increased to 78.27 in cycle II. 
2) The increasing of completeness percentage of students' learning results from cycle I to cycle II, students who complete the learning in the first cycle as many as 9 students or $34.6 \%$ increased in cycle II to 23 students or $88.5 \%$.

3) The Increasing activity of students in following the learning process from cycle I to cycle II

\section{REFERENCES}

Abdurrahman, Mulyono. 2003. Education for Children with Learning Difficulties. Jakarta: PT Rineka Cipta.

Badolo, Mas'ud. 2012. Guidelines and Techniques of Thesis Writing. Parepare.

Fajri, EM Zul \& Dusk, Queen Aprilia. 2007. Complete Dictionary of Indonesian Revised Edition. Jakarta: DIFA PUBLISHER.

Haling, Abdul. 2006. Learning and Learning. Makassar: Badan Penerbit Universitas Negeri Makassar.

Hamalik, Oemar. 2006. Teaching and Learning Process. Jakarta: Earth Literacy.

Hergenhahn, B. R. \& Olson, M.H. 2008. Theories of Learning. Jakarta: Kencana.

Hopkins, David. 1993. A Teacher's Guide to Classroom Research. Philadelphia: Open University Press.

Hudoyo, Herman. 1979. Development of Mathematics Curriculum and Its Implementation in Front of Classroom. Surabaya: National Business.

Ihsan, Fuad. 2005. Fundamentals of Education. Jakarta: Rineka Cipta.

Kunandar. 2011. Easy Step Classroom Action Research As Teacher Profession Development. Jakarta: PT Rajawali Press.

Luisha. 2012. Understanding of Learning Outcomes According to Experts. Available at (http://www.scribd.com/doc/87914090/51282702-Understanding-LearningAccording to-Ahli-Les). Retrieved on January 8, 2014.

Mulbar, Usman. 2013. Development of Mathematical Learning Model by Utilizing Social System Society. Yogyakarta: The Educational Horizon.

Purwanto. 2010. Evaluation of Learning Outcomes. Yogyakarta: Student Literature

Rusman. 2011. Learning Models (Developing Teacher Professionalism). Jakarta: Raja Grafindo Persada.

Soedjadi. 2000. Tips on Mathematics Education in Indonesia (Current Situation Conversion Towards Future Hope). Jakarta: Ministry of Education and Culture.

Shah, Muhibbin. 2006. Learning Psychology. Jakarta: Raja Grafindo Persada. 